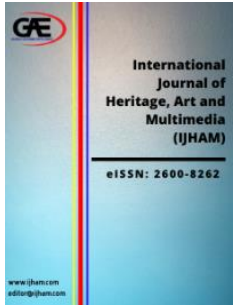

INTERNATIONAL JOURNAL OF HERITAGE, ART AND MULTIMEDIA

(IJHAM)

www.ijham.com

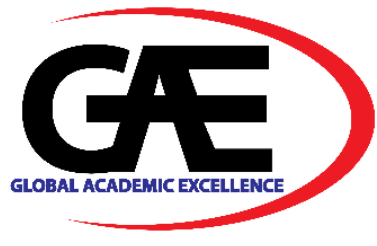

\title{
MALAY AND ISLAMIC TRADITIONS ELEMENTS THROUGH THE PAINTINGS OF MASTURA ABDUL RAHMAN, RUZAIKA OMAR BASAREEE AND HARON MOKHTAR
}

\author{
Ahmad Hakim Abdullah $^{1 *}$, Yuhanis Ibrahim², Mohammed Iqbal Badaruddin ${ }^{3}$ \\ 1 Faculty of Creative Technology and Heritage, Universiti Malaysia Kelantan,16300, Bachok, Kelantan, Malaysia. \\ Email: hakimabdullah08@gmail.com \\ 2 Faculty of Creative Technology and Heritage, Universiti Malaysia Kelantan,16300, Bachok, Kelantan, Malaysia. \\ Email: yuhanisibrahim@umk.edu.my \\ 3 Visual Art Department, Culture Centre, Institute For Advanced Studies, Universiti Malaya, 50603, Kuala Lumpur, \\ Malaysia. \\ Email: m_iqbal850@yahoo.com \\ * Corresponding Author
}

\section{Article Info:}

Article history:

Received date: 27.12 .2020

Revised date: 31.12 .2020

Accepted date: 06.01.2021

Published date: 03.03.2021

\section{To cite this document:}

Abdullah, A. H., Ibrahim, Y., \& Badaruddin, M. I. (2021). Malay and Islamic Traditions Elements through The Paintings of Mastura Abdul Rahman, Ruzaika Omar Basareee and Haron Mokhtar. International Journal of Heritage, Art and Multimedia, 4 (12), 01-16.

DOI: 10.35631/IJHAM.412001.

This work is licensed under CC BY 4.0

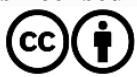

\section{Abstract:}

This study will highlight the elements of Islamic values and Malay traditions in the artworks of 20th and 21st-century Malaysian artists, namely Mastura Abdul Rahman, Haron Mokhtar, and Ruzaika Omar Basaree by discussing the elements of Malay values and Islamic traditions in respect of their artworks. The analyses focused on the artworks from 1980 to 2014, specifically Haron Mokhtar's "Zahir Mosque", Ruzaika Omar Basaree's "Siri Dungun" and Mastura Abdul Rahman's "House of Harmony" and "Interior No. 29". These artists' works were delivered according to the manifestation of the National Cultural Policy 1971, which highlighted the Islamic and local identity as the main idea and theme of the artworks of local artists. This study has used qualitative methods, which are documentation and observations of each work in the artists' catalogue as a process of collecting primary data. Meanwhile, secondary data were gathered through referencing academic works like books, journals, and magazines on Islamic values and Malay traditions in visual arts paintings. The analyses found that these works used Islamic art elements, like the "Thuluth" khat in "Zahir Mosque", as well as the combination of colour and flora motifs on "Siri Dungun". At the same time, they feature cultural elements, such as "congkak" and "Labu sayong" and traditional Malay ornamental design, which represent the Malay culture and philosophies. 
Keywords:

Expression of Malay and Islamic traditions, Paintings, Haron Mokhtar, Mastura Abdul Rahman, Ruzaika Omar Basaree

\section{Introduction}

The Malay-Islamic social image is an image featured in human expressions and culture and reflects the speciality of local craftsmen. The image of Malay culture is also found in local craft works (Noh, 2013). As such, the image of Malay-Islamic culture is highlighted in the artists' works. It is inferred that craftsmanship acts as the moderator of the message and its significance. Artworks could also be used to illustrate the way of life, which is characterized as conviction, customs, standards, and as well as, the workmanship of a specific culture (Ismail, 1986). This obviously shows the Malay - Islam elements have become the convention and way of life of the locals. It reflects the significance of the Malay Islamic culture in influencing the social Norms practiced every day, including common respect, mingling as warranted by Islamic law (Idris et al.,2016). In this regard, arts help remind Malay-Muslim individuals of these cultural conventions and religious laws so that they can live according to them.

The Malays should follow the Malay Islamic culture as it presents a guideline everyday living and stays as a custom for the public. (Ismail, 2014) explained the Malay-Muslims also practise crafts and arts, including paintings for leisure and to generate income. While some produce crafts to fill their free time, many craftsmen, have used their artworks a source of income. The creation of these painstaking artworks, including paintings is an element that upholds the Malay-Islamic culture. These paintings artworks have an aesthetic legacy that must be protected for people in the future (Abdullah et al.,2020). The craftsmanship in these works reflect the significance of the Malay-Islamic culture, which represent the identity of the Malays, and Malaysia as a country.

\section{Research Questions}

1. What is the intrinsic and extrinsic meaning of the Malay traditions and Islamic value in the artworks by Mastura Abdul Rahman, Ruzaika Omar Basaree, and Haron Mokhtar?

2. What is the subject of ideas and philosophies contained in the artworks by Mastura Abdul Rahman, Ruzaika Omar Basaree and Haron Mokhtar?

\section{Research Objectives}

1. To identify the intrinsic and extrinsic meaning of Malay traditions and the Islamic value in the artworks by Mastura Abdul Rahman, Ruzaika Omar Basaree, and Haron Mokhtar.

2. To examine the subject of ideas and philosophies contained in the artworks by Mastura Abdul Rahman, Ruzaika Omar Basaree, and Haron Mokhtar.

\section{Literature Review}

As indicated by (Mohamed et al.,2019), the expression of ideas in local artworks in highly influenced by the local culture and societal norms in the country. In this regard, Islam plays a significant component in receiving the way of life and societal norms. As a result, Malay and Islamic culture have become inter-dependent and non-distinct elements in local artists' expressions of human experiences. Islam recognises Allah as the magnificent and only God. 
Volume 4 Issue 12 (Mac 2021) PP. 01-16

DOI 10.35631/IJHAM.412001

This belief dictates the way or procedure to introduce the truth. Thus, 'greatness' in Islam reflect the qualities of Allah. This notion opposes the ideas of 'greatness' in the West (Abdul Kadir et al.,2018). Aside from the standards and reasoning of Tawhid in the craftsmanship of Malay fine arts, this study will dissect the themes of Malay-Muslim culture to examine how artwork could be used to spread and maintain the Islamic belief. As indicated by (Al-Jafari \& Ahmad, 2015), Islamic themes incorporate elements of flora which have gone through an innovative cycle. This implies the way to plan thoughts that incorporate Islamic craftsmanship with artistic worth.

Workmanship highlights the significance of framing and presenting the magnificence of the artwork (Khairuddin \& Wan Yusoff,2006). An artwork should not only contain stylistic elements in theory, it also should attract people's appreciation of the artwork, which are dependent on their acceptance and perspectives. Workmanship is as important in arts, just as structures are important in engineering. It presents a compelling artwork and designs that illustrate the craftsmen's innovativeness (Daud et al.,2012). In the Malay culture, workmanship reflects its cultural craftsmanship and serves as a fundamental aspect in the presentation of a "non-verbal" and three-dimensional topic.

\section{Methodology}

This paper presents a descriptive qualitative study where achievers documentation were conducted with selected academicians, artists catalogues. Moreover, the researchers also referred to journals, painter's works catalogues, books, and articles related to topic of this study. The researcher also referred to the National Art Gallery catalogues to observe these artworks through the visual method of recording. The artworks were then analysed based on their subject, design, and meaning. Data were also done through observation in the painters' studio. The study also focused on Muslim arts as well as Malay tradition. Hence, the researcher has referenced journals and books to study the Malay culture and Islamic traditions in the artworks of three local Malay artists in this modern Era.

\section{Theorical Backgrounds}

Table 1: The Comparisons Between Western And Islamic Art Philosophy Are Shown As Follows

\section{Basic Western Art Theory (Art Appreciation)}

Erwin Panofsky

Physical aspects

and externally

(Formalistic)
First - Main objects and subject of ideas

Expressions, factual, motifs

Second or conventional object of the topic of

Ideas and narration

Aspect of Meaning

(Content \& context) Intrinsic meaning or content, symbolism of the world Copyright (C) GLOBAL ACADEMIC EXCELLENCE (M) SDN BHD - All rights reserved 
Theory of Aesthetical Values by Imam Al-Ghazali

Imam Al-Ghazali Theory

Physical aspects $\quad$ External Beauty (dharir) or extrinsic values)

and External Details of the artists, titles, materials, etc.

How the subject is depicted (artistic elements).

How subjects are structured (design principles).

Aspect meaning The Meaning of internal beauty

Intrinsic values moral work.

Implied, meaning, interpretation.

The context of deeper understanding-introduction of Zikir, Nur, al-

khalik,

Tawhid, the hereafter and so on.

Appreciation of the meaning and higher knowledge or Islamic

philosophy-Sufi, Tasauf, and others.

Table 1 indicates according to Imam Al-Ghazali's theory of Aesthetical Values; the values of Malay culture and Islam are intertwined with one another in the production of these artworks. As described by (Dasuki et al.,2017), the thoughts of Imam Al-Ghazali are inherited by many thinkers, activists, and scholars of modern and contemporary arts such as Nakula, Sulaiman Esa, and Zakaria Ali. According to this theory, the values of beauty are directly related to the concept of Allah as the creator and the Most Beautiful. Imam Al-Ghazali's theory focuses on two aspects of aesthetics; the value of external beauty (luaran), which refers to the physical works of arts and the second is the meaning of inner beauty (dalaman) that refers to the morals in arts production.

Meanwhile, through the Erwin Panofsky theory (1940), the researcher will discuss the form and content of the Malay and Islamic traditions in Malaysian paintings from 1980 to 2014. The study follows the states theory that consists of three of understanding iconography, which are: 
a) Pre-iconography description:

This is the understanding and interpretation of meaning by familiar such as factual description from the visual surrounding the expressional connotations and what we see from it. Any-depth knowledge of the knowledge of the works and context does not require.

b) Iconographical analysis:

The more in-depth understanding of facts presented, and subject matter are required at this level. The analysis the requires an evaluation regarding the pre-iconographic materials., as can stay derived only out of a discussion on the concept and issues represented.

c) Iconological Interpretation:

This level involves the understanding of the content or intrinsic meaning of the artwork.it is also through people's knowledge of the world that linked to the artwork. Panofsky believes that this level is the ultimate goal of iconology. The last level is about the intrinsic meaning that defines the form and its content. At this stage, the researcher made the observations and focused on the interpretation that relates to the objective in identifying the Malay traditions and Islamic value in the artworks by Mastura Abdul Rahman, Ruzaika Omar Basaree and Haron Mokhtar. Then, he managed to find out the meaning of the form and relevant content.

\section{Results And Discussions}

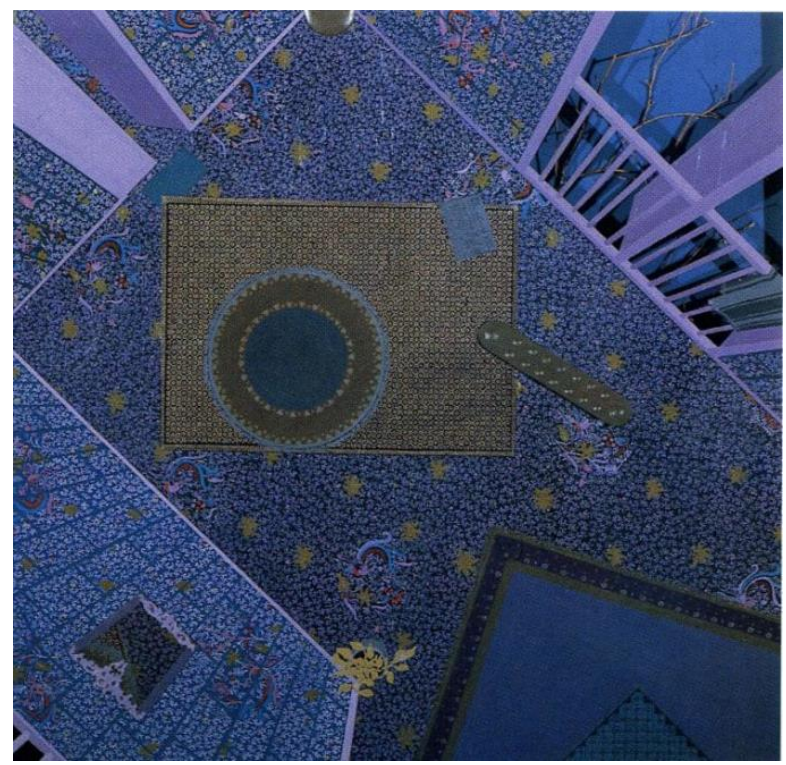

Figure 1: Mastura Abdul Rahman, “Interior No. 29" (1987), Mixed Media, $115 \mathrm{~cm} x$ $115 \mathrm{~cm}$.

(Source: https://mancala.fandom.com/wiki/Interior_No._29)

Congkak is a traditional game who has elements of Malayness in congkak game of the $21 \mathrm{st}$ century that has been essential in the lives of youths in the olden days. Apart from being a recreational activity, it also serves a platform to teach life skills to youths. Congkak is also popular activity among the Malay ladies at that time where it tests the players' ability to think and deduce across interesting theme and plan (Kechot, 2008). This traditional game has also gone through various changes over the years.

Copyright $\odot$ GLOBAL ACADEMIC EXCELLENCE (M) SDN BHD - All rights reserved 
Mastura Abdul Rahman depicts a congkak board (Figure 1) congkak boards are normally old and heavy, which are too enormous to be carried by the player, particularly children. The congkak has been given another breath, particularly in the drawing of young players and hues used. As indicated by the composition (Maizan, 2018), the colour of the congkak board material has been adjusted to change its appearance. Previously, Congkak has been attractive among youngsters yet these days, congkak boards have been designed creatively based on the modern structure to fit the trends and demands congkak players in this modern time (Sulaiman et al.,2019). The shade of the congkak board has given new varieties and more opportunity to light shading and change the shade of the players.

Undeniably, the dominance of western influence has negatively affected traditional Malay games. Furthermore, it leads to social conflicts between cultural practices and modern life. In this painting, the artist attempts to convey a message that the round of congkak has gone through numerous progressions in safeguarding the legacy of congkak as a traditional game. In this regard, it highlights that the youths have lost interest to participate in traditional games today. The Table 2 below shows the stated theory that consists is of two scholars understanding.

Table 2: Physical Aspects And Meaning Of The Work Of Interior 29 By Mastura Abdul Rahman

\begin{tabular}{|l|l|l|}
\hline & \multicolumn{1}{|c|}{$\begin{array}{c}\text { Theories of physical and external } \\
\text { aspects }\end{array}$} & \multicolumn{1}{c|}{ Aspects of internal meaning } \\
\hline $\begin{array}{l}\text { Imam Al- } \\
\text { Theory }\end{array}$ & $\begin{array}{l}\text { The beams and walls are painted } \\
\text { pink, which is commonly used in } \\
\text { houses of aristocrats. } \\
\text { Bright Colour }\end{array}$ & $\begin{array}{l}\text { The value of the interior design of the } \\
\text { Malay tradition House }\end{array}$ \\
\hline $\begin{array}{l}\text { Erwin } \\
\text { Panofsky of } \\
\text { Theory }\end{array}$ & Ornamental design of the carpet & $\begin{array}{l}\text { Traditional heritage of the Congkak } \\
\text { traditional game. }\end{array}$ \\
\hline & Floor and wall patterns & $\begin{array}{l}\text { Beauty of decorative Art in Bangsawan } \\
\text { (aristocrats) Malay House }\end{array}$ \\
\hline
\end{tabular}



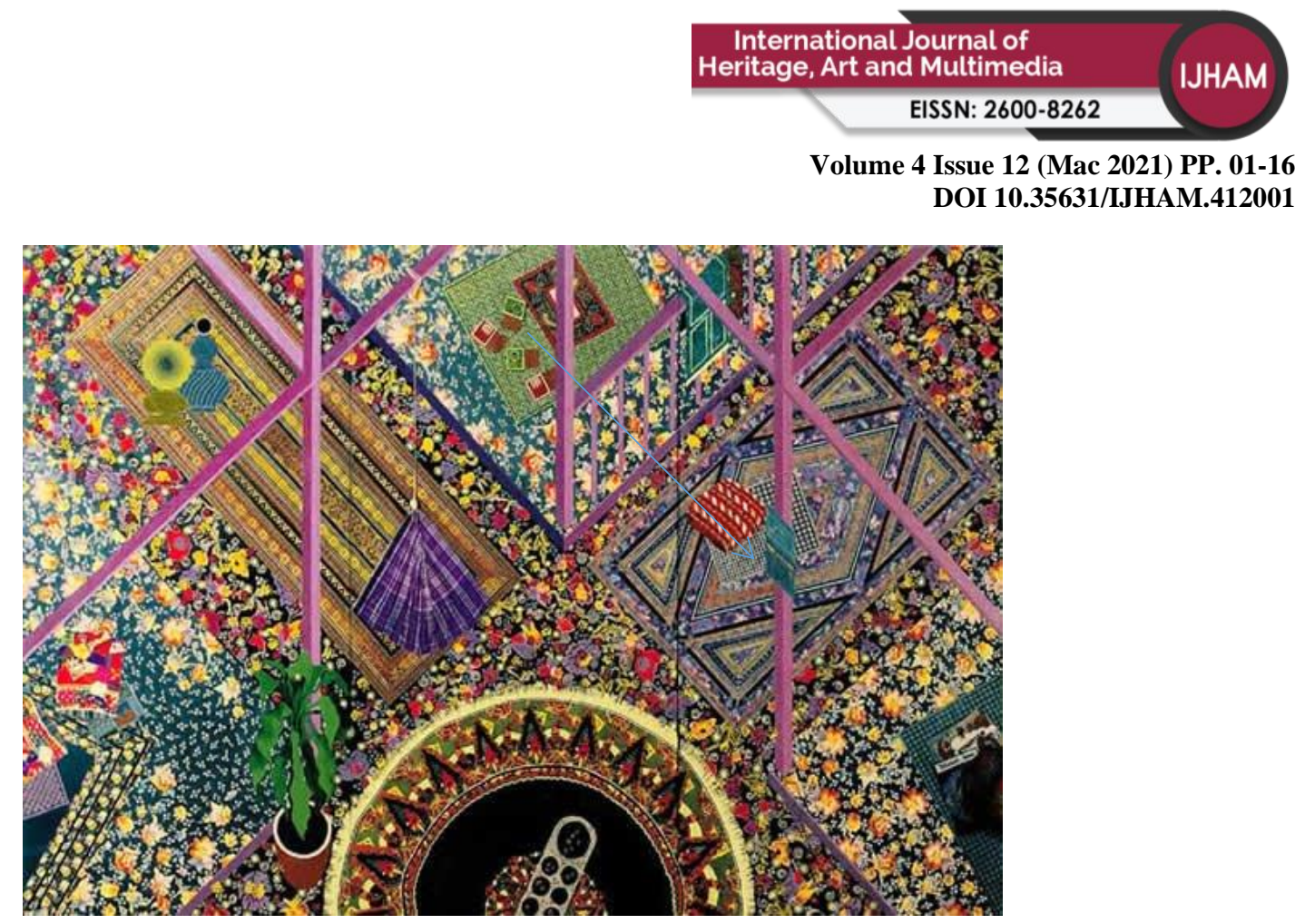

Figure 2: Mastura Abdul Rahman, House of Flowers, House of Harmony,1999 Mixed Media, $83 \mathrm{~cm}$ X $276 \mathrm{~cm}$

(Source: https://mancala.fandom.com)

Table 3: The Value Of The Physical Aspect And The Meaning In House Of Flowers, House Of Harmony By Mastura Abdul Rahman

\begin{tabular}{|l|l|l|}
\hline & $\begin{array}{l}\text { Theories of physical and external } \\
\text { aspects }\end{array}$ & Aspects of internal meaning \\
\hline $\begin{array}{l}\text { Imam Al- } \\
\text { Thazali of }\end{array}$ & Have a finesse and detailed motive & $\begin{array}{l}\text { The value of cultural materials, such as } \\
\text { Labu Sayong. } \\
\text { Islamic value as reflected by the Surah } \\
\text { Yassin and prayer Mats }\end{array}$ \\
\hline $\begin{array}{l}\text { Erwin } \\
\text { Panofsky } \\
\text { of Theory }\end{array}$ & $\begin{array}{l}\text { Colourful colour on design carpet } \\
\text { motifs }\end{array}$ & $\begin{array}{l}\text { To apply elements of motherhood, i.e the } \\
\text { baby swing. } \\
\text { The use of traditional Malay game, } \\
\text { specifically Congkak }\end{array}$ \\
\hline & The use of basic Colours & $\begin{array}{l}\text { Emphasis on religious values, such as } \\
\text { prayer mats and Surah Yassin }\end{array}$ \\
\hline
\end{tabular}

Labu sayong is a type of stoneware with rich and novel conventional qualities. It is frequently depicted through different structures and shapes that are inspired by characteristics different flora. Each labu sayong (Figure 2) features its own significance and reasoning through the consideration of different structures and theme. In this light, each labu sayong has explicit natural and extraneous implications inside the setting of the Malay imaginativeness. 
Volume 4 Issue 12 (Mac 2021) PP. 01-16 DOI 10.35631/IJHAM.412001

Based on its significance in the Malay culture, the labu sayong fine art by Mastura Abdul Rahman highlights several components of flora theme. It incorporates several components, including bamboo shoots (pucuk rebung), siku kluang, and potong wajik. There are many comparable works and comparative themes utilised over the years by Malay aesthetics specialists across peninsular Malaysia.

Dried pumpkins are the inspiration for the making of labu sayong in the traditional Malay society. Dried pumpkins were used as drink containers across communities in all states in peninsular Malaysia. Different imagination has contributed to the different types of labu sayong. A common inspiration is the head pumpkin (kepala labu) or otherwise called labu air, labu gelugur, and labu panai, while others have largely been ignored or just made upon request. As indicated by ( Ayob ,2019), the Malay people, general, value their ability to create highly attractive crafts. For example, several craftsmen used the puchung fowls (burung puchung) as the inspiration of labu sayong, as shown on its front. Meanwhile, the sides of the labu sayong resemble a water pumpkin (labu air). This demonstrates the careful and sharp perception put by the Malay craftsmen in adjusting the structures and shapes of the labu sayong.

The elements of Islam is also depicted in the expressions of Mastura's subject matter through the surah Yaasin (Table 3) which is normally recited by Muslims daily, particularly on Friday evenings. This was unmistakably clarified by (Idris et al., 2019), where the Malay- Muslims emphasise the social components in line with Islam, just as the community-based Islamica activities, including Maulidur rasul, Isra' Mi'raj, and congregational recitation of surah Yaasin. Moreover, Mastura illustrated the convention of Islamic decoration, which is illustrated by the structure of mosques and smaller than usual artistic creations.

Such angle unmistakably demonstrates Mastura's propensity on the issues of Islam, as the basic premise in the lives of the Malays with culture as its facilitator (Ismail, 2014). The Malays position Islam at its legitimate position. Islam fulfils the basic determinant of their knowledge and social qualities which influence their exceptional social personality. Along these lines, the Malays constantly need to remind themselves that their activities should not oppose the accepted way of life, convention, and above all, their religion. This is in line with the believe that convention should depends on the syara' and Quran.

Obedience to the religion has been a conspicuous aspect that frames the centre of the Malay character. Such commitment envelops the parts of faith, love, 'muamalah', 'muasyarah', and ethics. This is significant as religion influence the lifestyle that leads to the salvation the world and in the hereafter. This is exemplified in the Malay saying "biar mati anak, jangan mati adat" which implies that the way of life, custom, and convention can never be abused as they are framed by the Islamic laws and stated in the Quran.

As shown in Mastura's mixed media artworks, the sejadah, or the prayer mat, has a great significance to the Islamic faith. The prayer mat is portrayed as a warm, caring element in her fine art to reflect the significance of religion in her life. Furthermore, it also indicates Muslims protecting their modesty and respecting Allah by abstaining from setting a prayer mat at a dirty spot. Mastura presented the prayer mat as a rectangular mat with unmistakable Islamic emblems, especially at the top of the mat, where one will place their head during prayers. This represents an inherently important part of the prayer. 

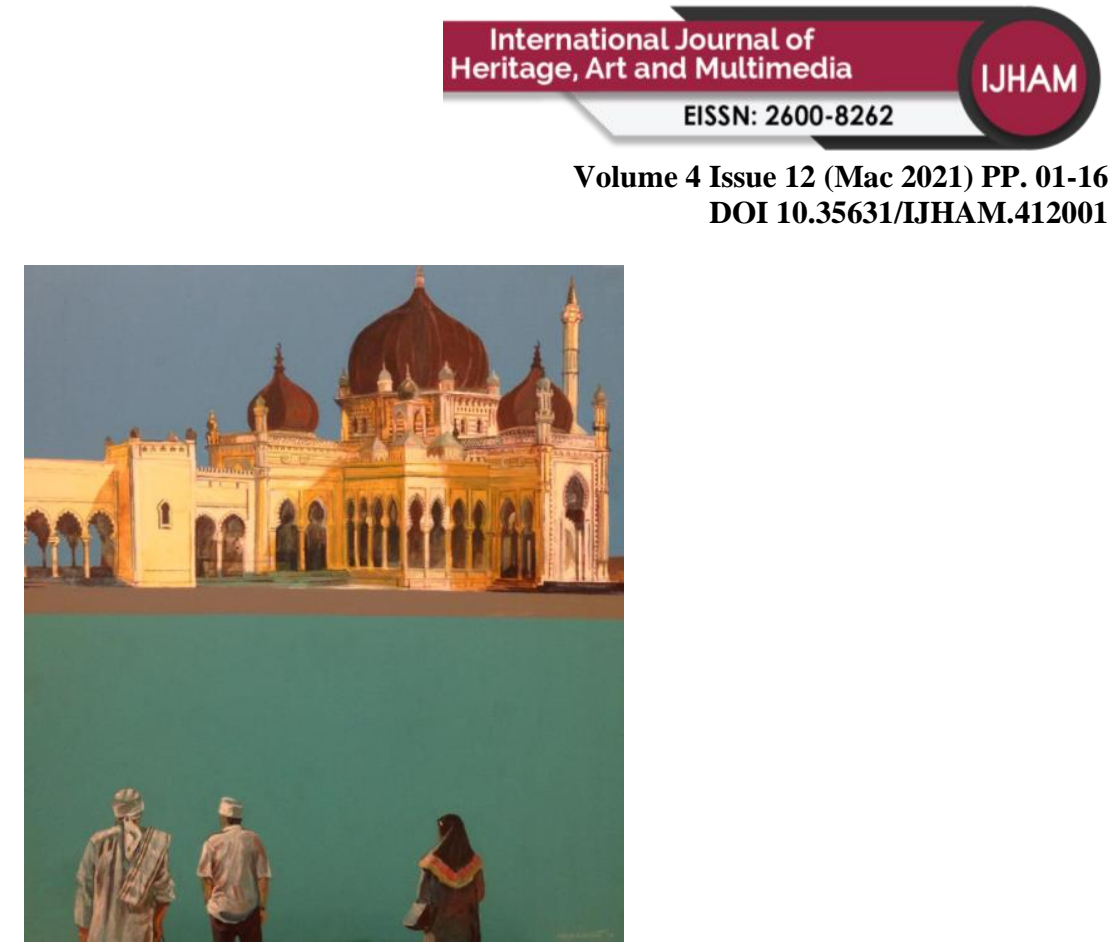

Figure 3: Haron Mokhtar,' Zahir Mosque', Acrylic Painting On Canvas, 2014, 81cm x $91 \mathrm{~cm}$

(Source: http://alamartsandcrafts.blogspot.com)

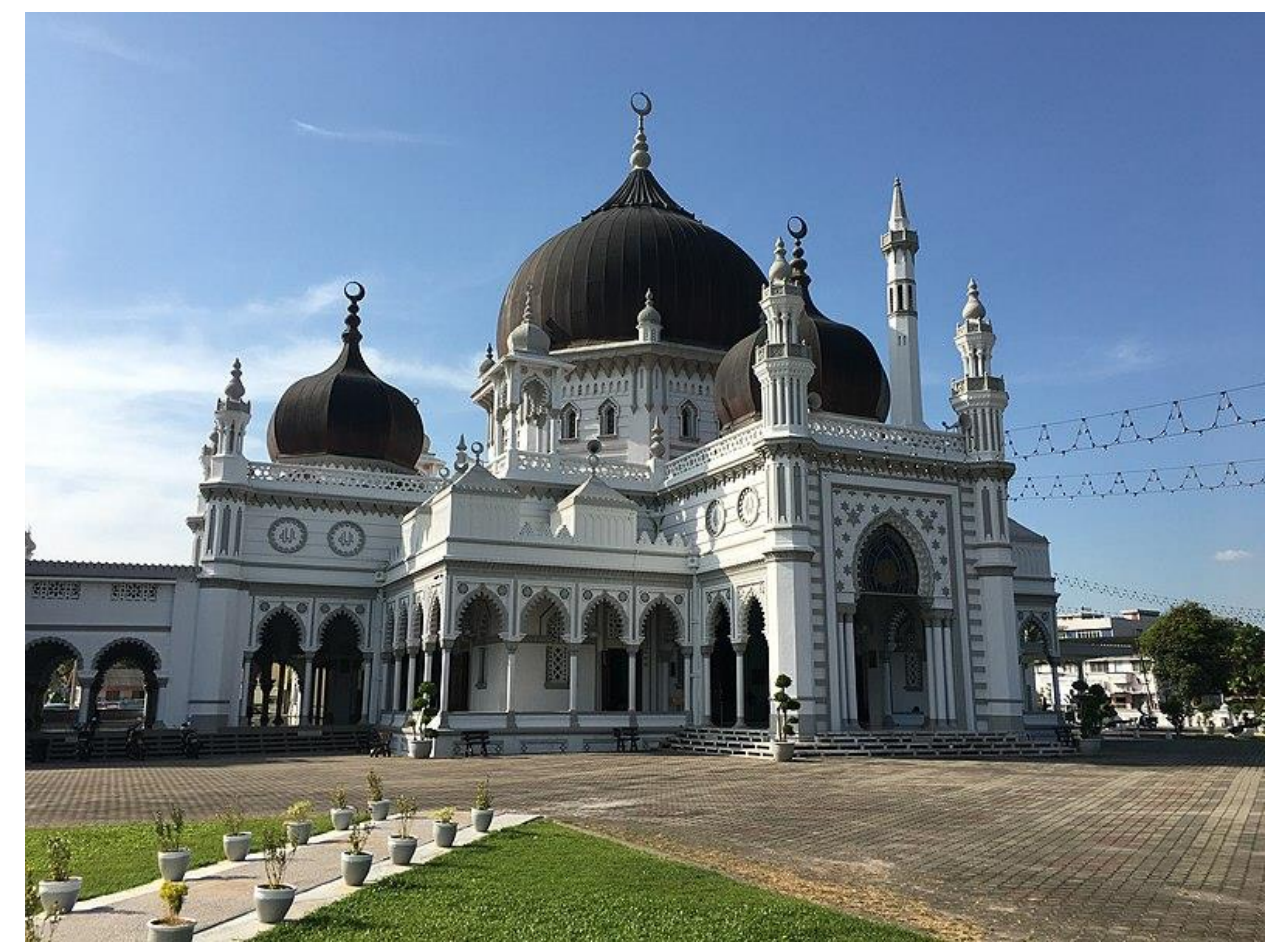

Figure 4: Frontal Views Of Actual Zahir Mosque

(Source: https://en.wikipedia.org/wiki/Zahir_Mosque) 
Volume 4 Issue 12 (Mac 2021) PP. 01-16 DOI 10.35631/IJHAM.412001

Table 4: The Physical Aspects And Meaning In The Artworks Of The Zahir Mosque By Haron Mokhtar

\begin{tabular}{|l|l|ll|}
\hline $\begin{array}{l}\text { Imam Al- } \\
\text { Ghazali of } \\
\text { theory }\end{array}$ & $\begin{array}{l}\text { Realistic looking mosque. } \\
\text { Colourful } \\
\text { Blue colour on the sky reflects } \\
\text { Allah as the creator } \\
\text { Cosmos motifs } \\
\text { The use of the Thuluth } \\
\text { Calligraphy }\end{array}$ & $\begin{array}{l}\text { Islamic Activities held by the } \\
\text { community } \\
\text { Humble value of a servant }\end{array}$ & \\
& $\begin{array}{l}\text { More realistic appearance in the } \\
\text { clothing } \\
\text { Panofsky of } \\
\text { Theory } \\
\text { Not revealing the faces of the } \\
\text { subject } \\
\text { The use of Khat Thuluth and } \\
\text { geometric lines on the wall of the } \\
\text { mosque. }\end{array}$ & $\begin{array}{l}\text { Communal activities and religious } \\
\text { lectures } \\
\text { Place of Islamic da'wah activities and } \\
\text { matters }\end{array}$ \\
\hline
\end{tabular}

Haron Mokhtar propelled Islamic thoughts in his work of art and highlighted Zahir mosque, which is the most known mosque in the state of Kedah. Haron used iconography to presents Islamic values through painting a man wearing robe, a man wearing a Kopiah (Figure 3) (skullcap) and a lady wearing the scarf who are looking at the mosque from the back. In this work, he focused on the structural elements by featuring three individuals who are dressed in an Islamic way. Aside from that, the painting features several other Islamic elements specifically calligraphy and cosmos elements, specifically stars as shown in Figure 4 above.

Haron also featured the themes of the mosque and Islamic calligraphy in this work, specifically the Thuluth (Figure 4) (Hussin et al., 2017). It is a lively and dynamic style of composition. This form of Calligraphy is mostly geometric and flexible. It gained popularity when it was introduced between the seventh and ninth century (Bakar,2012). Thuluth calligraphy is normally used on small surface, for example, books, calfskin books, magazines, and to write stanzas of the Qur'an in the olden days. Thuluth Jali is typically utilized as an embellishment in the inside of houses and mosques. It is also used in Masjid al-Haram. Highlighting calligraphy arts helps promote Jawi, which is part of the Islamic teaching throughout the Nusantara. (Ismail et al.,2016) expressed that Islam forbids the statute of creating special arts in contention to Islam. In this regard the Islamic Art of calligraphy is displayed in holy places like Mosques to be appreciated by individuals as they pray to Allah. Islamic craftsmanship, like Calligraphy are presented as arabesque and mathematical. Calligraphy is featured in mosques to illustrate Qur'an verses as expressed by Allah SWT.

Islamic craftsmanship features the evolution of Islamic knowledge from the past to the present. Present arts are not as elaborate as arts in previous ages that are profound enough to present magnificence of Allah through calligraphy. This artforms has also been used for a long time to illustrate the grandeur of the bygone age. In general, the painting features "Muhamad s.a.w" name to represent the prophet. In this regard, Islamic scholars, specifically Imam Maliki, Imam 
Hambali and Imam Ghazali, mentioned the significance of Prophet Muhammad SAW in the calligraphy featured in mosques.

\section{Masjid Zahir as Part of Islamic Activities Among The Islamic Community}

Haron's works underline the significance of his specialty, where the subject of mosques and Islamic images are inseparable in the depiction of Malay Muslims' everyday lives in the state of Kedah (Musa \& Adzaman 2020). The congregation in Kedah state Mosque is an essential element for the mosque's Islamic activities and as a way to spread Islam (Table 4). The mosque is viewed as the main site for spreading Islamic messages as the mosque is the main location spot to actualize da'wah exercises (Hanafiah, 2019).

The place of the mosque as a da'wah platform could not be denied. During the days of the prophet, The role of mosque in Islam is clear (Ismail, 2014). However, as indicated by (Daud et al., 2012), the position of mosques among the Islamic community has become insignificant specifically after the fall of the Islamic empire as the community sees mosques as is a type of a ceremonial building to adore, rather than a place for communal activities . Thus, the Muslim community needs to start organising more communal activities to re-establish its place in the community The capacities and functions of the mosque need to be diversified so that it can be inviting to the general population and (Basri, 2002). Mosques are the place to actualise the physical and otherworldly obligations of Islam and to fortify Muslims' faith towards Islam. In this light, any communal activities that could strengthen the Muslim community should conducted in mosques or their compound. A mosque is not just a spot to spread religion knowledge, it could also be a place to show non-Muslims the excellence of the Muslim community. Haron used his work to highlight Islamic arts and spread Islamic teaching by demonstrating the mosque's position for Muslim unity as well as a place to spread information on Islam. It highlights the need to expand the role of mosques among the modern Muslim community. Haron's artwork uphold the role of mosques in Islam. Henceforth, mosques especially in Kedah and Malaysia need to continuously retain their place as a place of da'wah and a symbol of Islamic unity.

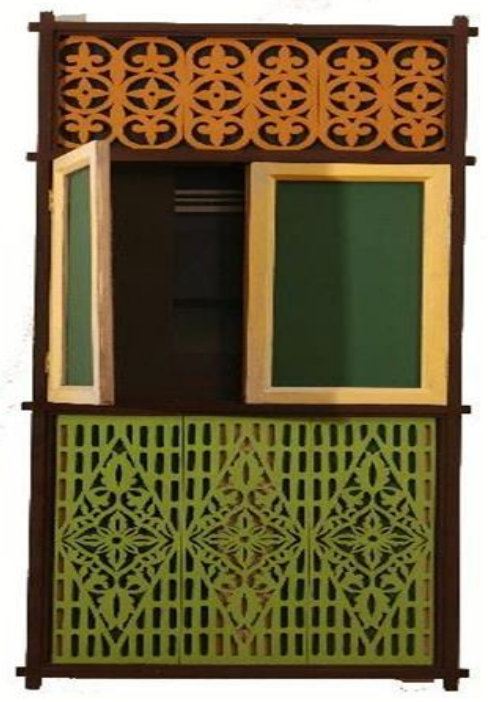

Figure 5: Ruzaika Omar Basaree, Siri Dungun (1981), Mixed Media (170.8cmx76c)

(Source. https://www.academia.edu) 
Table 5: Exhibit External Physical Aspects And Meanings Of Ruzaika Omar Basaree's Artworks

\begin{tabular}{|c|c|c|}
\hline & $\begin{array}{l}\text { Theories of physical and external } \\
\text { aspects }\end{array}$ & Aspects of internal meaning \\
\hline $\begin{array}{l}\text { Imam Al-Ghazali } \\
\text { of Theory }\end{array}$ & $\begin{array}{l}\text { Features the awan Larat motifs. } \\
\text { Uses geometric motifs and element. } \\
\text { Repetitions of elements, specifically } \\
\text { hand circle motifs indicating Eastern } \\
\text { influence. }\end{array}$ & $\begin{array}{l}\text { The use of 'Bunga Lawang' } \\
\text { (star anies) which is inspired } \\
\text { by traditional Malay } \\
\text { cuisines. }\end{array}$ \\
\hline $\begin{array}{l}\text { Erwin Panfosky of } \\
\text { Theory }\end{array}$ & $\begin{array}{l}\text { Application of harmonious colours. } \\
\text { Usage of cool colours like Green. } \\
\text { Use of symmetrical motifs in wood } \\
\text { carving. }\end{array}$ & $\begin{array}{l}\text { Design patterns used are } \\
\text { related to the nature of life } \\
\text { and the Malay-Islamic } \\
\text { culture. }\end{array}$ \\
\hline
\end{tabular}

Ruzaika Omar Basaree's artworks heavily featured the awan larat woodcarving which is commonly found in the state of Terengganu. Malay woodcarving is typically interconnected with the principles of Islamic craftsmanship, in view the Islamic 'Tauhid' which largely influenced the Islamic art style (Figure 5). Ruzaika's works attempt to stress the Malay way of thinking and the idea of Tauhid on the grounds that the Malay lifestyle and Islamic teachings should not be isolated from one another. As indicated by (Ali, 2008), the workmanship delivered by Ruzaika's "Siri Dungun" includes intricate and complex artworks as shown above. It presents the artistry featuring common social cultural activities in the Malay community. These elements could be identified with the accentuation of Malay carvings. Zakaria Ali described these elements as valuable, intertwined, converse, and edgy.

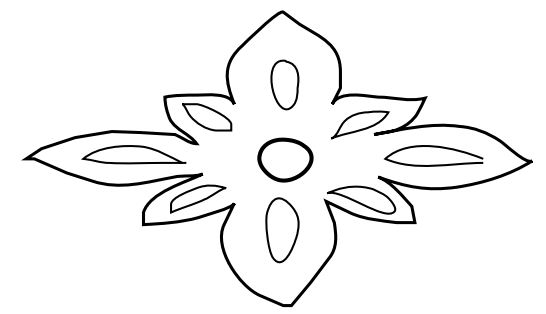

Figure 6: Bunga Lawang Motif Expressed Using The Adobe Illustrator Software. Bunga (Source: Researcher's collection). Lawang Motif As A Symbol Of The Malay Heritage

As shown in Table 5, the artwork is based on flora and natural theme. It features the bunga lawang (star anise), which was heavily used to represent the Malay customs in 'Siri Dungun' . As indicated by the composition (Sulaiman \& Husain 2019), Ruzaika Omar's works are inspired by nature. In this regard, the bunga lawang is revered in Malay culture due to its many benefits. Siri Dungun attempts to highlight bunga lawang which is a common ingredient in traditional Malay food (Table 5). The use of bunga Lawang (Figure 6) in traditional cooking makes it inseparable of the life of the Malays as it is a highly sought-after condiments in Malay cooking.

The artwork use flora as the theme in accordance Islamic teaching that forbids the use of animal or human forms. This work highlights the significance of flora and plants in the everyday lives 
Volume 4 Issue 12 (Mac 2021) PP. 01-16 DOI 10.35631/IJHAM.412001

of the Malay community as well as the Malays' appreciation of Allah's creations. The use of plants is related to the prohibition of using animals and human forms as arts. In this light, the Islamic influence inspire the Malays to value Allah's creations.

\section{Geometric Motif of Bamboo Shoots representing the Islamic Concept of Tauhid}

The 'awan Larat' motif presents a conventional workmanship corresponding to Islamic way of thinking and the Malay traditions. The bunga Lawang motif featured by Ruzaika Omar Basaree presents shapes of the genuine bunga Lawang despite its impractical look. The Islamic values in the work (lesson of significant worth) can be found through various qualities that can be distinguished in Islamic fine arts. The inspiration comes from the appreciation of the artist to nature and to Allah, as its creator (Hamat \& Yusoff, 2020). This characteristic impacts the regular life of the Malays and inspired the creatively and innovativeness within the Malay the community since the olden time (Yatim, 1989). Islamic workmanship presented in these artworks embrace the Malay culture and philosophies that influence the Malay-Islamic way of thinking, as reflected by the awan Larat motif which features inspirations of flora and calligraphy that do not resemble any animals or human forms.

Regarding the composition (Dasuki et al., 2017), it highlights the traditional customary expressions which are largely inspired by nature. In this regard, the inspiration is isolated from any western influence. In their portrayals, the artists acknowledge and consider the Islamic workmanship component (Abdullah \& Samin, 2020). Consequently, the ideas and treatment of themes or 'content' are presented through geometric shapes such as polygons, triangles, rectangles and pentagons. This highlights the use geometry and angles in Islamic visual craftsmanship (Zakaria, 2012). These geometric elements are infused with Islamic arts components, for example, Jawi scripts or calligraphy in accordance to Islamic laws.

The cultural theme creates a character and intricacies to the works of Ruzaika Omar Basaree. It presents the significance of the Malay culture in shaping the themes. The works feature an assortment of elements to represent Allah, human lives, and nature, such as the bamboo shoot. This is on the grounds that God as the creator has created fascinating flora that should be valued and appreciated by all humans. For instance, the scattered Bamboo shoots structure design emphasises the different imaginative themes particularly in the craftmanship demonstrated by markers of batik, Songket, wood carvings, fine metal workmanship, and custom home designs.

\section{Recommendation}

The artworks analysed in this study uses the cultural themes of Malay and Islamic traditions. They are able to highlight art patterns that still maintain the traditional and Islamic values but are based on the current trends. relation to this, art trends and awareness play an important role in increasing exposure to Islamic traditional art and Islam as well as the appreciation of these artworks. Islamic religious values are emphasised as an important element in the national culture. At the same time, the influence of other cultures is also acknowledged, as long as they do not oppose the Islamic culture. It is hereby significant that the artists, academics, and researchers work together to maintain the traditional culture so that it can be ingrained among Malaysians. 
Volume 4 Issue 12 (Mac 2021) PP. 01-16 DOI 10.35631/IJHAM.412001

\section{Conclusion}

Malay and Islamic arts have long existed since ancient times as an expression of people's adoration of Allah creation. This artforms presents a clear limit that leads to the betterment of faith and keeps Muslims away from any harm. Artists like Mastura Abdul Rahman, Ruzaika Omar Basaree and Haron Mokhtar presented artworks that are inspired by the cultural characteristics of Malay and Islamic traditions and changed the trends of modern. The establishment of the National Cultural Congress in 1971 has given a positive impact to Malay artists. It has highlighted of the work of these artists, which are inspired by cultural art and the Islamic world. This study has analysed the beauty of these artworks from the Islamic perspective. These artworks have featured Malay traditions and adapted the Malay cultural values and philosophy.

The use of Jawi scripts, calligraphy, awan Larat carving, and traditional games of Congkak has helped beautify the images in the artists' treatment of the subject. This has provided a positive impact to the country and the local arts industry in presenting the Malay-Muslim identity and traditions. Thus, these artworks are local art treasures that need to be preserved. While there are some influences of Western and foreign cultures are, they are not stressed in these artworks. This is because local artists have undergone changes in thoughts and influence where they strive to preserve the value of Malay traditions and philosophy so they can be cherished by the future generation.

\section{Acknowledgements}

The authors would like to thank you for Mohammed Iqbal Badaruddin for his cooperation of the teams, this study was able to be done smoothly. As such, we would like to thank all the people who were involved in this study. This paper was presented at MICOLLAC 2020 (11th Malaysia International Conference on Languages, Literatures and Cultures), organised by Universiti Putra Malaysia.

\section{References}

Abdul Kadir, N. A., Dahalan, N., Naemah, N., \& Jamaludin, N. (2018). Art in Islam: A special study of sculpture art. E-Journal of Islamic Thought and Understanding, 1(1), 1-15.

Abdullah,A.H., Ibrahim.Y., \& Khalid,R.I.R. (2020) An Iconographical Analysis Based on the Erwin Panofsky Theory on the Malayness in The paintings of Amron Omar and Haron Mokhtar. International Journal of Academic Research in Business and Social Sciences. 10 (9), 589-601.

Abdullah, A.H., \& Samin, M.A. (2020). The Sustainability of Flora, Fauna and Geometric Motif Designs Among Batik Tulis Manufacturers in Klang Valeey. International Journal of Heritage, Art and Multimedia, 3 (9),11-24.

Ali, Z. (1989), Art and artists: art essays, Kuala Lumpur: Dewan Bahasa dan pustaka, 3.

Al Jafari,S. M. A. T., \& Ahmad, B. (2015). Mosque waqf periodically in Singapura according to the syariah perspective. Jurnal Pengurusan dan Penyelidikan Fatwa, 5, 125-139.

Ayob, S. (2019). Malay Sayong pottery tradition: Stating the origin of the essence of form,motif and appearance. Journal of Applied Arts, 1(1), 73-77.

Bakar, A. L.B.A. (2012). Identity and patriotism centered on the history,constitution, and policies of the government . Tanjung Malim: Universiti Pendidikan Sultan Idris.

Basri, F. (2002). Mosque architecture in Malaysia. Jurnal Tasawwur Islam, 5, 61-69. 
Volume 4 Issue 12 (Mac 2021) PP. 01-16 DOI 10.35631/IJHAM.412001

Dasuki, S., Abdulah, N. H., Idris, N., Mohd Radzi, F., \& Ali, S. (2017). The beauty of the concept of unity in the design motifs of Malay tradition. Proceedings of second International Islamic Heritage Conference. (pp.239-253). Academy of Contemporary Islamic: Studies, Universiti Teknologi MARA.

Daud, N. I. M. K., Arbi, A., \& Faisal, M. (2012). Malay wood carving application in architecture in Malaysia. Journal of Design and Built Environment, 11, 1-14.

Hamat, M. R., \& Yusoff, M. Y. M. (2020). Flora motifs in the art of Kelantan fine metal carving .Jurnal Melayu, 19(1).

Hanafiah, M. G. (2019).Heresy Issue of the Malay community practices: Mass media discourse analysis. Jurnal Komunikasi: Malaysian Journal of Communication, 35(2).

Hussin, R., Mokhtar, A., \& Jabbar, A. R. A. (2017). The art of calligraphy (khat) in the Mihrab of Malaysian state mosques and its relationship with visual art. KUPAS SENI: Jurnal Seni dan Pendidikan Seni, 5.

Idris, N., Omar Basaree, R.., Radzi,F.M ., Mohamed Yussof,F., Zahari, F \& Dasuki, S. (2016) Compilation Theories of Malay aesthetics:Concept of Malay Beauty in Arts. Proceedings Pengukuhan Budi \& Jati Diri. (pp.86-94).Fakulti Seni Lukis dan Seni Reka :Universiti Teknologi MARA.

Ismail, A.R. (2014), Art and Malay fabrics: nature as a fabric motif handicraft of traditions wither, Shah Alam.Penerbit Universiti Teknologi MARA.

Idris, N., Mohammad Noh, L. M., \& Abdul Rahim, M. H. (2019).The concept of monotheism as a contextual analysis in the design Masjid Tengkera Melaka. Jurnal Inspirasi Seni Intelektual, 16-25.

Ismail, A.R., Roshdi, S.M., Hassan, A.R. (2016). Nature as a source of design motifs of the decorative arts of the Malay community fabric, Proceeding Pengukuhan Budi \& Jati Diri (pp.95-103).Fakulti Seni Lukis dan Seni Reka. Universiti Teknologi MARA.

Ismail, S. Z. (1986). Malay handicraft design tradition. Kuala Lumpur: Dewan Bahasa dan Pustaka.

Kechot, A.S.(2008) Foundation of Malay culture and arts. Jurnal Melayu, 3. 1-8.

Maizan, S. (2018). Congkak Variations through Design Transformation. IDEOLOGY, 3(3), 114-126.

Mohamed, S., Mokhtar, M., \& Zain, D. H. M.(2019). The Application of Qur'anic Verses in Malaysian Contemporary Islamic Painting and Fashion: 1991-2016. In Contemporary Management and Science Issues in the Halal Industry: Proceedings of the International Malaysia Halal Conference (pp.1-28).Springer. Singapore.

Musa, A. H., \& Adzaman, M. T. N. (2020). Thematic Analysis of Self-Experience, Cultural Expression and Islamic Expression on Haron Mokhtar's Series of Paintings. IDEOLOGY, 5(1), 17-22.

Noh, L. M. M. (2013). Manifestation in various worldviews form and soul shape of the Malay women paintings in 1970-1990, Proceeding Seminar Penyelidikan Pemikiran dan Kepimpinan Melayu.(pp.98-106).Perpustakaan Tun Abdul Razak:Universiti Teknologi MARA.

Rizali, N. (2012). The position of art in Islam. Tsaqafa-Jurnal Kajian Seni Budaya Islam, 1(1), $1-8$.

Sulaiman, R., \& Husain, H.(2019).Appreciation of Siri Dungun Paintings in Ethnomathematics Context. KUPAS SENI : Jurnal Seni Dan Pendidikan Seni, 7, 1-11. 
Volume 4 Issue 12 (Mac 2021) PP. 01-16 DOI 10.35631/IJHAM.412001

Sulaiman, R., Husain, A. H., \& Sulaiman, R. (2019). Appreciation of Siri Dungun Paintings in Ethnomathematics Context. International Journal of Academic Research in Business and Social Sciences, 9(9).

Khairuddin, A. H., \& Wan Yusoff, W. A. K. (2006). Food in society and culture: collecting words to the dictionary as the preservation of Malay cultural heritage. Perpustakaan Tun Abdul Razak:Universiti Teknologi MARA. Retrieved Oct 18, 2016, from http://melayu.library.uitm.edu.my/346/

Yatim, O. M. (1989). Artistic heritage in Islam, Kuala Lumpur: Dewan Bahasa dan Pustaka.

Zakaria, I. (2012). Islam and Its Philosophy in Malay Culture .Jurnal Hadhari: An International Journal, 91-108 